\title{
Fibronectin-1 expression is increased in aggressive thyroid cancer and favors the migration and invasion of cancer cells
}

\author{
Marialuisa Sponziello a, 1 , Francesca Rosignolo ${ }^{\text {a, }}{ }^{\text {, }}$, Marilena Celano ${ }^{\text {b }}$, \\ Valentina Maggisano ${ }^{b}$, Valeria Pecce ${ }^{a}$, Roberta Francesca De Rose ${ }^{b}$, \\ Giovanni Enrico Lombardo b, Cosimo Durante a, Sebastiano Filetti a, Giuseppe Damante ${ }^{\text {, }}$ \\ Diego Russo $^{\text {b, * , Stefania Bulotta }}{ }^{\text {b }}$ \\ a Department of Internal Medicine and Medical Specialties, “Sapienza” University of Rome, 00161, Rome, Italy \\ b Department of Health Sciences, “Magna Graecia” University of Catanzaro, 88100, Catanzaro, Italy \\ c Institute of Medical Genetics, “S. Maria della Misericordia” University Hospital, 33100, Udine, Italy
}

\section{A R T I C L E I N F O}

\section{Article history:}

Received 21 December 2015

Received in revised form

5 May 2016

Accepted 8 May 2016

Available online 10 May 2016

\section{Keywords:}

EMT

Fibronectin

Thyroid cancer

BRAF

\begin{abstract}
A B S T R A C T
In this study we analyzed the expression levels of markers of epithelial-to-mesenchymal transition (EMT) in several papillary thyroid carcinomas (PTCs) and the relation with tumor genotypes and clinicopathological characteristics. The role of fibronectin-1 (FN1) was investigated by analyzing the effects of FN1 silencing in two human thyroid cancer cell lines.

Most of EMT markers were significantly over-expressed in a group of 36 PTCs. In particular, FN1 mRNA levels were higher in tumor $v s$ non-tumor tissue $(117.3, \mathrm{p}<0.001)$ and also in aggressive and $\mathrm{BRAF}^{\mathrm{V} 600 \mathrm{E}}$ samples. Similar results were observed (and confirmed at the protein level) when FN1 expression was analyzed in a validation group of 50 PTCs and six lymph node (LN) metastases. Silencing of FN1 in TPC-1 and BCPAP thyroid cancer cells significantly reduced proliferation, adhesion, migration, and invasion in both cell lines.

Collectively, our data indicate that FN1 overexpression is an important determinant of thyroid cancer aggressiveness.
\end{abstract}

๑) 2016 Elsevier Ireland Ltd. All rights reserved.

\section{Introduction}

The incidence of differentiated thyroid carcinoma (DTC) has increased over the past decade (Udelsman and Zhang, 2014; Mehra et al., 2015). Although the majority of patients have an excellent prognosis, the management of invasive tumors and/or distant metastases is still a major clinical challenge, especially those that are unresponsive to radioiodine therapy (Schlumberger et al., 2007;

Abbreviations: ATA, American Thyroid Association; DTC, differentiated thyroid carcinoma; ECM, extracellular matrix; EMT, epithelial-to-mesenchymal transition; FNAB, fine needle aspiration biopsy; FN1, fibronectin-1; IR, intermediate risk; LN, lymph node; LR, low risk; PARP1, Poly (ADP-ribose) polymerase 1; PTC, papillary thyroid carcinoma; PTC-CL, classic PTC; PTC-FV, follicular-variant PTC; TLDA, TaqMan Low Density Array.

* Corresponding author. Department of Health Sciences, University "Magna Graecia" of Catanzaro, Campus "S. Venuta”, Viale Europa, 88100, Catanzaro, Italy.

E-mail address: d.russo@unicz.it (D. Russo).

1 Equal contribution.
Carneiro et al., 2015). For these tumors, improved understanding of the molecular alterations responsible for their aggressive behavior could lead to the development of new treatment options (Bulotta et al., 2016).

The epithelial-to-mesenchymal transition (EMT) is an essential step in cancer progression: it provides cancer cells with the capacity to migrate from the primary tumor, invade surrounding tissues, and reach distant sites (Thiery and Sleeman, 2006; Huber et al., 2005). Vasko et al. (2007) showed that an expression profile consistent with EMT is common in invasive papillary thyroid carcinomas (PTCs) and highlighted the roles played in this process by vimentin and other extracellular matrix (ECM) proteins. Subsequently, another EMT marker, periostin, was reported to be overexpressed in PTC, and its mRNA levels were positively correlated with extrathyroidal invasion, distant metastasis, and higher grade staging (Puppin et al., 2008). Interestingly, ECM alterations have been described as a consequence of the $\mathrm{BRAF}^{\mathrm{V} 600 \mathrm{E}}$ mutation (Nucera et al., 2011), the most common genetic alteration detected in human PTCs, and increasing bodies of in vitro and in vivo data 
suggest that this mutation is associated with invasive properties and aggressive behavior in thyroid cancer (Durante et al., 2007; Puxeddu et al., 2008; Nucera et al., 2009; Knauf et al., 2011).

In this study, we investigated the gene expression levels of 27 EMT markers in group of 36 PTCs classified as intermediate or low risk (IR or LR) tumors according to current criteria published by the American Thyroid Association (ATA) (Haugen et al., 2016). Fibronectin-1 (FN1), a fundamental component of the ECM, was the marker most strikingly upregulated in IR-PTCs relative to those classified as LR-PTC, and this finding was validated in a second series of PTCs, which also included metastatic lymph node (LN) tissues. Small-interfering RNA-mediated silencing of FN1 in two human thyroid cancer cell lines clearly demonstrated the involvement of FN1 in the viability, adhesion, migration, and invasive properties of thyroid cancer cells.

\section{Materials and methods}

\subsection{Collection of thyroid tissues}

The study protocol was preapproved by the institutional ethics committee. Tumor tissues and normal thyroid tissues were prospectively collected from consenting 86 patients consecutively subjected to total thyroidectomy for sporadic PTC at the "Sapienza" University Hospital of Rome between 2009 and 2014. Tissue samples were excluded if tumor sample cellularity was less than $60 \%$, and/or if normal thyroid tissue from the uninvolved lobe exhibited signs of inflammation or other types of disease. All 86 PTCs were also used to study the expression of thyroid-specific differentiation markers, and those results have been described elsewhere (Sponziello et al., 2015; Rosignolo et al., 2015).

Samples of tumor tissue $(\mathrm{n}=86,36$ in the screening group and 50 in the validation group), $L N$ metastases ( $n=6$, all from cases in the validation series) and normal thyroid tissue ( $n=42$, including 18 in the screening group and 24 in the validation group) were collected and immediately frozen after thyroidectomy. For each tumor, the risk of recurrence was classified as LR or IR in accordance with the 2015 ATA Guidelines for the Management of Adult Patients with Thyroid Nodules and Differentiated Thyroid Cancer (Haugen et al., 2016). BRAF mutational status was determined by Sanger sequencing, as previously described (Passon et al., 2015). PTC histotypes were determined by histopathological examination. The clinical and pathological characteristics of the screening and validation groups are summarized in Table 1 .

\subsection{Extraction of RNA and gene expression studies}

Total RNA was isolated from tissues using TRIzol reagent (Thermo Fisher Scientific Inc., Waltham, MA, USA) according to the manufacturer's protocol, quantified with a NanoDrop Spectrophotometer (Thermo Fisher Scientific), and reverse-transcribed with a High Capacity cDNA Reverse Transcription kit (Thermo Fisher Scientific). The expression of 27 EMT-related genes was then assessed using a TaqMan Low Density Array (TLDA), and mRNA levels of FN1

Table 1

Clinical data of PTC patients at the time of primary treatment.

\begin{tabular}{|c|c|c|}
\hline Clinicopathological features $^{a}$ & Screening group $(\mathrm{n}=36)$ & Validation group $(n=56)$ \\
\hline \multicolumn{3}{|l|}{ Age at diagnosis } \\
\hline Patients $<45 \mathrm{yr}$ & $17(47.2)$ & $29(51.8)$ \\
\hline Patients $\geq 45 \mathrm{yr}$ & $19(52.8)$ & $27(48.2)$ \\
\hline \multicolumn{3}{|l|}{ Gender } \\
\hline Male & $11(30.6)$ & $20(35.7)$ \\
\hline Female & $25(69.4)$ & $36(64.3)$ \\
\hline \multicolumn{3}{|l|}{ Tumor size } \\
\hline$\geq 1 \mathrm{~cm}$ & $27(75.0)$ & $42(75.0)$ \\
\hline$<1 \mathrm{~cm}$ & $9(25.0)$ & $14(25.0)$ \\
\hline \multicolumn{3}{|l|}{ Multifocality ${ }^{\mathrm{b}}$} \\
\hline Yes & $11(30.6)$ & $10(17.9)$ \\
\hline No & $25(69.4)$ & $35(62.5)$ \\
\hline \multicolumn{3}{|l|}{ Extrathyroidal extension ${ }^{c}$} \\
\hline Yes & $14(38.9)$ & $24(42.9)$ \\
\hline No & $22(61.1)$ & $30(53.6)$ \\
\hline \multicolumn{3}{|l|}{ Lymph node metastases ${ }^{\mathrm{b}}$} \\
\hline Yes & $11(30.6)$ & $24(42.9)$ \\
\hline No & $25(69.4)$ & $31(55.4)$ \\
\hline \multicolumn{3}{|l|}{ ATA risk $^{\mathrm{b}, \mathrm{d}}$} \\
\hline Low & $12(33.3)$ & $13(23.2)$ \\
\hline Intermediate & $24(66.7)$ & $42(75.0)$ \\
\hline \multicolumn{3}{|l|}{ BRAF mutational status } \\
\hline wt & $15(41.7)$ & $16(28.6)$ \\
\hline V600E & $20(55.6)$ & $40(71.4)$ \\
\hline V600_K601 > E & $1(2.8)$ & 0 \\
\hline \multicolumn{3}{|l|}{ Histological variant } \\
\hline PTC-CL & $31(86.1)$ & $45(80.4)$ \\
\hline PTC-FV & $5(13.9)^{e}$ & $9(16.1)^{f}$ \\
\hline PTC-other & 0 & $2(3.6)$ \\
\hline
\end{tabular}

Validation group includes 6 lymph nodes.

Abbreviations: ATA, American Thyroid Association; PTC, papillary thyroid carcinoma; PTC-CL, classic PTC; PTC-FV, follicular-variant PTC; wt, wild-type.

a Results are reported as numbers (\%) of patients in the screening and validation groups.

b Data not available for one patient.

c Data not available for two patients.

d American Thyroid Association risk stratification staging system (Haugen et al., 2016).

e One sample showed extrathyroidal extension.

f Three samples showed extrathyroidal extension. 
were further analyzed by real-time PCR, as described previously (Sponziello et al., 2013).

All qPCR assays were performed on a 7900 HT Fast Real-time PCR System (Thermo Fisher Scientific), Ct values were calculated with SDS 2.4 software (Thermo Fisher Scientific), and data were analyzed with RQ Manager 1.2.1 software (Thermo Fisher Scientific). Final results were determined by the comparative $2^{-\Delta \Delta \mathrm{Ct}}$ method using $\beta$-actin as endogenous control.

After all analysis, expression levels in normal thyroids were averaged and indicated as 1 , and the expression levels in cancer were expressed as the ratio to the levels of average in normal thyroids.

\subsection{Protein extraction and western blot analysis}

Total proteins were extracted as previously described (D’Agostino et al., 2012; Sponziello et al., 2015). Extracts (30 $\mu \mathrm{g}$ of protein) were run on a $5 \%$ or $12 \%$ SDS-PAGE gel, transferred to PVDF membranes (VWR, Milan, Italy), blocked with TTBS/milk (TBS, 1\% Tween $20,5 \%$ non-fat dry milk) or TTBS/BSA (TBS, $1 \%$ Tween $20,5 \%$ BSA), and incubated overnight with affinity-purified anti-FN1 (Sigma Aldrich, Milan, Italy), anti-ERK1/2 (Cell Signaling, Danvers, MA, USA), anti-phospho-ERK1/2 (Cell Signaling), and anti- $\beta$-actin antibodies (Sigma Aldrich), diluted 1:1000, 1:1000, 1:2000, and $1: 10000$, respectively. The membranes were washed in TTBS and incubated with horseradish peroxidase-conjugated anti-rabbit or anti-mouse antibody (Transduction Laboratories, Lexington, KY, USA) in TTBS/milk, diluted 1:5000 or 1:20000 respectively. The protein was visualized by chemiluminescence using the Western blot detection system ECL Plus (Perkin Elmer, Monza, Italy).

\subsection{Thyroid cancer cell lines, treatments, and FN1 silencing}

Two human PTC cell lines were used for in vitro experiments. TPC1 and BCPAP, characterized by RET/PTC1 rearrangement and $\mathrm{BRAF}^{\mathrm{V} 600 \mathrm{E}}$ mutation, respectively (Schweppe et al., 2008), were cultured as previously described (Bulotta et al., 2013). Short tandem repeat profiling was used to authenticate these cell lines. Immortalized, non-tumorigenic Nthy-ori-3-1 (European Collection of Authenticated Cell Culture) cells were grown in RPMI medium (ThermoFisher Scientific) supplemented with $10 \%$ fetal bovine serum (FBS, ThermoFisher Scientific), penicillin $(100 \mathrm{IU} / \mathrm{ml})$, streptomycin $(100 \mathrm{mg} / \mathrm{ml})$, and amphotericin B $(2.5 \mathrm{mg} / \mathrm{ml})$ (Sigma Aldrich).

$\mathrm{BCPAP}$ cells were treated with the selective BRAF ${ }^{\mathrm{V} 600 \mathrm{E}}$ inhibitor PLX4032 (Vemurafenib, RG7204) (Selleck Chemicals, Houston, TX, USA), as previously reported (Xing et al., 2011). Briefly, cells were plated onto medium containing FBS $5 \%$ in 6 well plates $\left(7 \times 10^{5} /\right.$ well). Twenty-four hours later, PLX4032 (0.0, 0.01, 0.10, 0.30, 1.00, and $3.00 \mu \mathrm{M}$ ) was added and plates incubated for $24 \mathrm{~h}$. The inhibition of $\mathrm{BRAF}^{\mathrm{V} 600 \mathrm{E}}$ was confirmed by western blot analysis of phospho-ERK1/2. Primary antibodies against ERK1/2 and $\beta$-actin were used as controls.

For FN1 silencing, we used three different FN1 specific siRNA (siFN1) (sequences 5'-3': a. CAGUCAAAGCAAGCCCGGUUGUUAU; b. GCAGUGGCUGAAGACACAAGGAAAU; c. GGGACUUCCUAUGUGGUCGGAGAAA). Cells were transiently transfected using Lipofectamine RNAiMAX (ThermoFisher Scientific), in accordance with the manufacturer's instructions. Cells were plated onto medium containing FBS $10 \%$ in 6 well plates (TPC-1, $1.5 \times 10^{5} /$ well and BCPAP $2 \times 10^{5}$ /well) and had reached $60-80 \%$ confluence at the time of transfection. Forty-eight hours after transfection, changes in FN1 protein expression were assessed with Western blot and immunofluorescence assays. Cells transfected with Stealth RNAi Negative Control Duplexes (ThermoFisher Scientific) were used as controls (indicated as siCtrl) in all experiments.

\subsection{Immunofluorescence assay}

After FN1 silencing, cells were fixed in 4\% paraformaldehyde, treated with Triton X-100, and processed for immunofluorescence as described previously (Bulotta et al., 2006). Briefly, cells were immunostained for FN1 using a monoclonal anti-FN1 antibody (Sigma Aldrich) at 1:100 dilution and then incubated with Alexa Fluor 555 anti-mouse antibody from Molecular Probes (Thermo Fisher Scientific) at 1:800 dilution. Finally, cell DNA was stained with Hoechst 33258 (ThermoFisher Scientific) and observed with a Leica TC-SP2 confocal microscope.

\subsection{Analysis of cell viability}

Cell viability was evaluated by MTT (Maggisano et al., 2014) and cell count assays (Celano et al., 2015). After FN1 silencing, two assays were performed as follows: (a) for MTT, TPC- 1 and BCPAP cells were seeded in 96 well plates, at a density of $3 \times 10^{3}$ or $6 \times 10^{3}$ for well, respectively. After $24 \mathrm{~h}$ of incubation, culture medium was replaced with fresh medium containing MTT, and its solubilized product formazan was quantified with a microplate spectrophotometer (xMark, Biorad, Milan, Italy) at a wavelength of $540 \mathrm{~nm}$ and a reference wavelength of $690 \mathrm{~nm}$; (b) for cell count, TPC-1 and BCPAP cells were seeded in 12 well plates at a density of $1 \times 10^{4}$ or $2 \times 10^{4}$ for well, respectively, and incubated for $24 \mathrm{~h}$. Viable cells were counted in chamber slides (Countess, automated cell counter, ThermoFisher Scientific) after Trypan blue staining. Results are expressed as percentages over cells transfected with Stealth RNAi Negative Control Duplexes (ThermoFisher Scientific), used as control (siCtrl).

\subsection{Adhesion, migration and invasion assays}

Adhesion assays were performed as previously described (Liu et al., 2005; Bulotta et al., 2009). Briefly, after FN1 silencing, $5 \times 10^{4}$ cells were plated into 24 well plates coated with collagen I (BD, Milan, Italy) and incubated for $1 \mathrm{~h}$; then, unattached cells were removed with $\mathrm{PBS}$ and adherent cells were fixed in $4 \%$ paraformaldehyde for $15 \mathrm{~min}$, stained with $0.1 \%$ Crystal Violet solution for 10 min and washed with $\mathrm{H}_{2} \mathrm{O}$. The stain was solubilized in $10 \%$ acetic acid and cell attachment was quantified by measurement of absorbance at $560 \mathrm{~nm}$ with xMark microplate spectrophotometer (Biorad).

Cell migration was evaluated using Transwell inserts with $8 \mu \mathrm{m}$ pore (Constar, Euroclone, Milan, Italy), as previously described (Bulotta et al., 2009). To assess invasiveness, Transwell inserts were coated with Matrigel (BD). After silencing, $5 \times 10^{4}$ cells were suspended in serum-free medium containing $1 \%$ BSA (for migration assay) or $1 \%$ FBS (for invasion assay) and plated in the upper chamber of the inserts. The bottom wells contained $600 \mu \mathrm{L}$ of medium with $10 \%$ FBS as a chemotactic agent. After incubation (6 h and $24 \mathrm{~h}$ for migration and invasion assays, respectively), cells that had not migrated were removed from the upper surface of the filters with cotton swabs, and the filters were fixed and stained with Diff-Quick Stain (Bio Map, Monza, Italy). Two different operators counted migrated and invasive cells in eight random microscopic fields (magnification 10x) using an eyepiece with a counting grid. Results are expressed as percentages over cells used as control (siCtrl).

\subsection{Statistical analysis}

Results are expressed as mean \pm standard deviations (SD). For cell proliferation, migration, and invasion assays, we used a oneway ANOVA followed by the Tukey-Kramer multiple comparisons 
test. The Mann-Whitney test with Bonferroni correction was used to assess differences in gene expression levels between two groups of samples; the Kruskal Wallis test, followed by Dunn's multiple comparisons test was used when three or more groups were compared. P-values lower than 0.05 were considered statistically significant. All statistical analyses were performed using GraphPad Prism version 5.0 statistical software (GraphPad Software Inc., San Diego, CA, USA).

\section{Results}

\subsection{Expression levels of EMT genes in PTC}

As shown in Table 1, the 36 PTCs in the screening group included 24 that classified as IR and 12 that were LR according to ATA criteria (Haugen et al., 2016). These tumors were also characterized by the presence or absence of the $B R A F^{V 600 E}$ mutation (Table 1). TLDA analysis revealed that most of the EMT-related genes examined were significantly overexpressed in tumor tissues compared with levels observed in normal thyroid tissues (Table 2). The most substantial upregulation involved mRNA levels for FN1 (increased 117.3 fold, $\mathrm{p}<0.0001$ ). Interestingly, the increase over normal levels was even more striking when analysis was restricted to the following subgroups: PTCs displaying the classic histotype (PTC-CL) (136 fold increase $v s$ normal thyroid tissue, $\mathrm{p}<0.0001$ ) (Supplemental Table 1), IR-PTCs (148 fold, $\mathrm{p}<0.0001$ ) (Table 3), and PTCs harboring the $B R A F^{V 600 E}$ mutation (148 fold, $\mathrm{p}<0.001$ ) (Table 4).

Subsequent experiments were thus focused on the expression of FN1, extending our investigation to a second series of PTC tissues (validation group), which included 42 IR-PTCs, 13 LR-PTCs, and 6 LN metastases. Forty of these PTCs carried the BRAF $F^{V 600 E}$ mutation. Real-time PCR analysis showed that expression levels of FN1 were significantly increased in tumors and LN metastases relative to levels in normal tissues ( $\mathrm{p}<0.001$ and $\mathrm{p}<0.05$, respectively)
(Fig. 1A). Again, a significant up-regulation was also found in the subgroups of IR-PTCs $(\mathrm{p}<0.001)$ and the $B R A F^{V 600 E}$ PTCs $(\mathrm{p}<0.001)$ (Fig. 1B, C). FN1 mRNA levels were increased in the PTC-CL subgroup ( $\mathrm{p}<0.05$ vs the follicular-variant PTC [PTC-FV] subgroup) (Fig. 1D), in IR-PTCs ( $\mathrm{p}<0.05$ vs LR-PTC), and in $B R A F^{V 600 E}$ PTC ( $\mathrm{p}<0.01$ vs BRAF-wt PTCs) (Fig. 1B, C). FN1 mRNA levels were not significantly different in subgroups defined by the presence/ absence of extrathyroidal extension or of LN metastasis (data not shown).

Western blot analysis was performed in the protein extracts available from a representative series of IR-PTCs and their normal counterpart. As shown in Fig. 2, higher levels of FN1 protein expression were present in tumor tissue compared with the normal counterpart.

\subsubsection{Effects of siRNA-mediated silencing of FN1 on the} proliferation, adhesion, migration, and invasiveness of thyroid cancer cells

Small interfering RNA-mediated FN1 silencing experiments were done on TPC-1 and BCPAP cells, which show higher expression levels of FN1 than those in the non-tumorigenic cell line Nthyori-3-1 (panel A of Fig. 3). Three specific siRNA were used (siFN1 a, b, c). All three produced significant decreases in the levels of FN1 protein expression as compared with control siRNA (siCtrl)-transfected or non-transfected cells (ctrl) (Fig. 3B, C). In cells transfected with siFN1, cell viability decreased in TPC- 1 and BCPAP cells ( 20-30\%, p $<0.05$, and $\sim 40 \%, \mathrm{p}<0.01$ vs siCtrl, respectively) (Fig. 4). Silencing of FN1 in TPC-1 and BCPAP cell lines also significantly reduced cell adhesion $(\sim 20 \%, \mathrm{p}<0.01$, and $\sim 30 \%$, $\mathrm{p}<0.01$, vs siCtrl, respectively), migration ( 40\%, p $<0.01$, and $\sim 50-60 \%$ $\mathrm{p}<0.001$, vs siCtrl, respectively), and invasion $(\sim 40 \%, \mathrm{p}<0.001, v s$ siCtrl) (Fig. 5). FN1 protein expression was also reduced in BCPAP cells by treatment with the $\mathrm{BRAF}^{\mathrm{V} 600 \mathrm{E}}$ kinase inhibitor, PLX4032 (Fig. 6).

Table 2

mRNA expression of EMT markers in PTCs compared to normal tissues from the screening group.

\begin{tabular}{|c|c|c|c|c|}
\hline & NT $(\mathrm{n}=18)$ & $\operatorname{PTC}(\mathrm{n}=36)$ & p Value (Mann-Whitney test) & p Value (Bonferroni correction) \\
\hline \multicolumn{5}{|l|}{ ECM degradation } \\
\hline COL5A1 - Hs00609088_m1 & $1 \pm 0.52$ & $10.97 \pm 20.56$ & 0.0005 & 0.0135 \\
\hline CTSB - Hs00947433_m1 & $1 \pm 0.44$ & $2.01 \pm 0.10$ & $<0.0001$ & 0.0027 \\
\hline ECM1 - Hs00189435_m1 & $1 \pm 0.49$ & $19.59 \pm 36.42$ & $<0.0001$ & 0.0027 \\
\hline LAMB3 - Hs00165078_m1 & $1 \pm 0.88$ & $86.25 \pm 88.29$ & $<0.0001$ & 0.0027 \\
\hline LOX - Hs00184700_m1 & $1 \pm 0.52$ & $1.43 \pm 1.38$ & ns & ns \\
\hline LOXL2 - Hs00158757_m1 & $1 \pm 0.37$ & $4.65 \pm 5.89$ & $<0.0001$ & 0.0027 \\
\hline MMP2 - Hs01548727_m1 & $1 \pm 0.55$ & $0.72 \pm 0.59$ & ns & ns \\
\hline MMP9 - Hs00234579_m1 & $1 \pm 1.09$ & $5.15 \pm 13.78$ & 0.0223 & 0.6021 \\
\hline PLAU - Hs01547054_m1 & $1 \pm 0.45$ & $16.66 \pm 15.28$ & $<0.0001$ & 0.0027 \\
\hline PLAUR - Hs00958880_m1 & $1 \pm 0.72$ & $7.88 \pm 6.90$ & $<0.0001$ & 0.0027 \\
\hline TIMP3 - Hs00165949_m1 & $1 \pm 0.37$ & $3.12 \pm 12.72$ & ns & ns \\
\hline \multicolumn{5}{|l|}{ ECM adhesion } \\
\hline CDH1 - Hs01023894_m1 & $1 \pm 0.54$ & $1.73 \pm 2.11$ & ns & ns \\
\hline CDH2 - Hs00983056_m1 & $1 \pm 1.46$ & $10.23 \pm 16.04$ & $<0.0001$ & 0.0027 \\
\hline CDH11 - Hs00901475_m1 & $1 \pm 0.45$ & $2.66 \pm 3.19$ & 0.008 & 0.216 \\
\hline CDH16 - Hs00187880_m1 & $1 \pm 0.65$ & $0.07 \pm 0.09$ & $<0.0001$ & 0.0027 \\
\hline FN1 - Hs00365052_m1 & $1 \pm 0.49$ & $117.27 \pm 149.19$ & $<0.0001$ & 0.0027 \\
\hline SPP1 - Hs00959010_m1 & $1 \pm 1.19$ & $3.93 \pm 4.08$ & 0.0003 & 0.0081 \\
\hline VIM - Hs00185584_m1 & $1 \pm 0.41$ & $1.14 \pm 1.38$ & ns & ns \\
\hline \multicolumn{5}{|l|}{ Transcription factors } \\
\hline SNAI1 - Hs00195591_m1 & $1 \pm 0.45$ & $0.53 \pm 0.73$ & $<0.0001$ & 0.0027 \\
\hline SNAI2 - Hs00950344_m1 & $1 \pm 0.66$ & $0.44 \pm 0.34$ & 0.0002 & 0.0054 \\
\hline SNAI3 - Hs01018996_m1 & $1 \pm 0.57$ & $2.55 \pm 3.78$ & 0.0063 & ns \\
\hline SPRY4 - Hs00229610_m1 & $1 \pm 0.46$ & $2.85 \pm 2.05$ & $<0.0001$ & 0.0027 \\
\hline STAT3 - Hs00374280_m1 & $1 \pm 0.47$ & $1.76 \pm 1.49$ & 0.0105 & ns \\
\hline TCF3 - Hs00413032_m1 & $1 \pm 0.45$ & $1.68 \pm 1.19$ & 0.0348 & ns \\
\hline TWIST1 - Hs01675818_s1 & $1 \pm 0.47$ & $1.44 \pm 1.72$ & ns & ns \\
\hline ZEB1 - Hs00232783_m1 & $1 \pm 0.52$ & $0.57 \pm 0.38$ & 0.0002 & 0.0054 \\
\hline ZEB2 - Hs00207691_m1 & $1 \pm 0.51$ & $0.75 \pm 0.60$ & 0.0158 & ns \\
\hline
\end{tabular}

ECM, extracellular matrix; EMT, epithelial-to-mesenchymal transition; ns, not significant; NT, normal thyroid tissues; PTC, papillary thyroid carcinoma. 
Table 3

mRNA expression of EMT markers in tumor tissues of low risk PTC and intermediate risk PTC compared to normal tissues from the screening group.

\begin{tabular}{|c|c|c|c|c|c|c|c|}
\hline & \multirow{2}{*}{$\mathrm{NT}(\mathrm{n}=18)$} & \multirow{2}{*}{ Low risk $^{\mathrm{a}}(\mathrm{n}=12)$} & \multirow{2}{*}{ Intermediate risk $^{\mathrm{a}}(\mathrm{n}=24)$} & \multirow{2}{*}{$\frac{\mathrm{p} \text { Value }}{\text { (Kruskal Wallis test) }}$} & \multicolumn{3}{|c|}{ p Value (Dunn's test) } \\
\hline & & & & & NT vs low risk & NT vs intermediate risk & Low Risk vs intermediate risk \\
\hline \multicolumn{8}{|c|}{ ECM degradation } \\
\hline COL5A1 & $1 \pm 0.52$ & $4.38 \pm 7.48$ & $14.27 \pm 24.14$ & $<0.0001$ & ns & $<0.001$ & $<0.05$ \\
\hline$C T S B$ & $1 \pm 0.44$ & $1.62 \pm 0.92$ & $2.20 \pm 1.00$ & $<0.0001$ & ns & $<0.001$ & ns \\
\hline ECM1 & $1 \pm 0.49$ & $24.48 \pm 42.60$ & $17.15 \pm 33.63$ & $<0.0001$ & $<0.001$ & $<0.001$ & ns \\
\hline LAMB3 & $1 \pm 0.88$ & $61.29 \pm 53.45$ & $98.73 \pm 100.04$ & $<0.0001$ & $<0.01$ & $<0.001$ & ns \\
\hline LOX & $1 \pm 0.52$ & $0.75 \pm 0.64$ & $1.77 \pm 1.53$ & 0.033 & ns & ns & $<0.05$ \\
\hline LOXL2 & $1 \pm 0.37$ & $2.88 \pm 3.04$ & $5.52 \pm 6.77$ & $<0.0001$ & ns & $<0.001$ & ns \\
\hline MMP2 & $1 \pm 0.55$ & $0.49 \pm 0.40$ & $0.83 \pm 0.64$ & 0.0358 & $<0.05$ & ns & ns \\
\hline MMP9 & $1 \pm 1.09$ & $7.92 \pm 23.51$ & $3.76 \pm 4.32$ & 0.0019 & ns & $<0.01$ & $<0.05$ \\
\hline PLAU & $1 \pm 0.45$ & $11.63 \pm 13.48$ & $19.17 \pm 15.77$ & $<0.0001$ & $<0.01$ & $<0.001$ & ns \\
\hline PLAUR & $1 \pm 0.72$ & $5.58 \pm 5.35$ & $9.04 \pm 7.39$ & $<0.0001$ & $<0.01$ & $<0.001$ & ns \\
\hline TIMP3 & $1 \pm 0.37$ & $0.69 \pm 0.55$ & $4.33 \pm 15.54$ & ns & ns & ns & ns \\
\hline \multicolumn{8}{|c|}{ ECM adhesion } \\
\hline CDH1 & $1 \pm 0.54$ & $1.35 \pm 1.70$ & $1.92 \pm 2.30$ & ns & ns & ns & ns \\
\hline $\mathrm{CDH} 2$ & $1 \pm 1.46$ & $13.62 \pm 24.69$ & $8.53 \pm 9.53$ & 0.0002 & $<0.01$ & $<0.001$ & ns \\
\hline$C D H 11$ & $1 \pm 0.45$ & $1.44 \pm 1.40$ & $3.28 \pm 3.66$ & 0.0009 & ns & $<0.01$ & $<0.05$ \\
\hline $\mathrm{CDH} 16$ & $1 \pm 0.65$ & $0.08 \pm 0.07$ & $0.07 \pm 0.10$ & $<0.0001$ & $<0.001$ & $<0.001$ & ns \\
\hline FN1 & $1 \pm 0.49$ & $55.31 \pm 93.07$ & $148.25 \pm 163.47$ & $<0.0001$ & ns & $<0.001$ & $<0.05$ \\
\hline SPP1 & $1 \pm 1.19$ & $2.26 \pm 2.81$ & $4.76 \pm 4.40$ & $<0.0001$ & ns & $<0.001$ & $<0.05$ \\
\hline VIM & $1 \pm 0.41$ & $1.06 \pm 1.01$ & $1.19 \pm 1.55$ & ns & ns & ns & ns \\
\hline \multicolumn{8}{|c|}{ Transcription factors } \\
\hline SNAI1 & $1 \pm 0.45$ & $0.43 \pm 0.37$ & $0.59 \pm 0.86$ & 0.0003 & $<0.01$ & $<0.001$ & ns \\
\hline SNAI2 & $1 \pm 0.66$ & $0.32 \pm 0.29$ & $0.50 \pm 0.35$ & 0.0002 & $<0.001$ & $<0.05$ & ns \\
\hline SNAI3 & $1 \pm 0.57$ & $2.99 \pm 5.87$ & $2.32 \pm 2.18$ & 0.0098 & ns & $<0.01$ & ns \\
\hline SPRY4 & $1 \pm 0.46$ & $2.99 \pm 2.16$ & $2.78 \pm 2.03$ & 0.0002 & $<0.001$ & $<0.01$ & ns \\
\hline STAT3 & $1 \pm 0.47$ & $1.37 \pm 1.21$ & $1.95 \pm 1.61$ & 0.0046 & ns & $<0.01$ & ns \\
\hline TCF3 & $1 \pm 0.45$ & $1.40 \pm 1.04$ & $1.82 \pm 1.26$ & ns & ns & $<0.05$ & ns \\
\hline TWIST1 & $1 \pm 0.47$ & $0.68 \pm 0.46$ & $1.83 \pm 2.00$ & ns & ns & ns & $<0.05$ \\
\hline ZEB1 & $1 \pm 0.52$ & $0.45 \pm 0.17$ & $0.63 \pm 0.45$ & 0.0007 & $<0.01$ & $<0.01$ & ns \\
\hline ZEB2 & $1 \pm 0.51$ & $0.50 \pm 0.45$ & $0.86 \pm 0.64$ & 0.009 & $<0.01$ & ns & ns \\
\hline
\end{tabular}

ECM, extracellular matrix; EMT, epithelial-to-mesenchymal transition; ns, not significant; NT, normal thyroid tissues; PTC, papillary thyroid carcinoma.

a American Thyroid Association risk stratification staging system (2016).

Table 4

mRNA expression of EMT markers in tumor tissues of PTC BRAF-wt and PTC BRAF ${ }^{\mathrm{V} 600 \mathrm{E}}$ compared to normal tissues from the screening group.

\begin{tabular}{|c|c|c|c|c|c|c|c|}
\hline & \multirow[t]{2}{*}{$\mathrm{NT}(\mathrm{n}=18)$} & \multirow[t]{2}{*}{ BRAF-wt $(\mathrm{n}=15)$} & \multirow[t]{2}{*}{$\mathrm{BRAF}^{\mathrm{V} 600 \mathrm{E}}(\mathrm{n}=20)$} & \multirow{2}{*}{$\frac{\mathrm{p} \text { Value }}{\text { (Kruskal Wallis test) }}$} & \multicolumn{3}{|c|}{ p Value (Dunn's test) } \\
\hline & & & & & NT vs BRAF-wt & NT vs BRAF ${ }^{\mathrm{V} 600 \mathrm{E}}$ & BRAF-wt vs BRAF ${ }^{\mathrm{V} 600 \mathrm{E}}$ \\
\hline \multicolumn{8}{|c|}{ ECM degradation } \\
\hline COL5A1 & $1 \pm 0.52$ & $13.78 \pm 27.56$ & $8.96 \pm 14.08$ & 0.0016 & $<0.05$ & $<0.01$ & ns \\
\hline CTSB & $1 \pm 0.44$ & $1.51 \pm 0.82$ & $2.36 \pm 0.97$ & $<0.0001$ & $\mathrm{~ns}$ & $<0.001$ & $<0.05$ \\
\hline ECM1 & $1 \pm 0.49$ & $39.97 \pm 49.66$ & $5.04 \pm 7.80$ & $<0.0001$ & $<0.001$ & $<0.01$ & ns \\
\hline LAMB3 & $1 \pm 0.88$ & $67.24 \pm 53.11$ & $99.83 \pm 105.84$ & $<0.0001$ & $<0.001$ & $<0.001$ & ns \\
\hline LOX & $1 \pm 0.52$ & $1.25 \pm 1.77$ & $1.56 \pm 1.05$ & ns & ns & ns & ns \\
\hline LOXL2 & $1 \pm 0.37$ & $5.57 \pm 8.05$ & $3.99 \pm 3.77$ & 0.0001 & $<0.01$ & $<0.001$ & ns \\
\hline MMP2 & $1 \pm 0.55$ & $0.80 \pm 0.82$ & $0.65 \pm 0.35$ & ns & ns & ns & ns \\
\hline MMP9 & $1 \pm 1.09$ & $7.68 \pm 20.99$ & $3.34 \pm 3.99$ & 0.038 & ns & $<0.05$ & ns \\
\hline PLAU & $1 \pm 0.45$ & $19.17 \pm 20.16$ & $14.86 \pm 10.78$ & $<0.0001$ & $<0.001$ & $<0.001$ & ns \\
\hline PLAUR & $1 \pm 0.72$ & $8.43 \pm 7.98$ & $7.49 \pm 6.20$ & $<0.0001$ & $<0.001$ & $<0.001$ & ns \\
\hline TIMP3 & $1 \pm 0.37$ & $1.03 \pm 1.02$ & $4.60 \pm 16.64$ & ns & ns & ns & ns \\
\hline \multicolumn{8}{|c|}{ ECM adhesion } \\
\hline $\mathrm{CDH} 1$ & $1 \pm 0.54$ & $1.59 \pm 1.75$ & $1.84 \pm 2.37$ & ns & ns & ns & ns \\
\hline $\mathrm{CDH} 2$ & $1 \pm 1.46$ & $6.48 \pm 5.31$ & $12.90 \pm 20.31$ & 0.0002 & $<0.01$ & $<0.001$ & ns \\
\hline$C D H 11$ & $1 \pm 0.45$ & $2.85 \pm 4.71$ & $2.53 \pm 1.50$ & 0.0032 & ns & $<0.01$ & ns \\
\hline$C D H 16$ & $1 \pm 0.65$ & $0.10 \pm 0.11$ & $0.05 \pm 0.06$ & $<0.0001$ & $<0.001$ & $<0.001$ & ns \\
\hline FN1 & $1 \pm 0.49$ & $73.79 \pm 101.68$ & $148.33 \pm 171.12$ & $<0.0001$ & $<0.05$ & $<0.001$ & ns \\
\hline SPP1 & $1 \pm 1.19$ & $2.53 \pm 2.51$ & $4.92 \pm 4.71$ & 0.0003 & ns & $<0.001$ & ns \\
\hline VIM & $1 \pm 0.41$ & $1.06 \pm 0.89$ & $1.20 \pm 1.66$ & ns & ns & $\mathrm{ns}$ & ns \\
\hline \multicolumn{8}{|c|}{ Transcription factors } \\
\hline SNAI1 & $1 \pm 0.45$ & $0.87 \pm 1.02$ & $0.28 \pm 0.15$ & $<0.0001$ & ns & $<0.001$ & $<0.05$ \\
\hline SNAI2 & $1 \pm 0.66$ & $0.52 \pm 0.47$ & $0.38 \pm 0.21$ & 0.0006 & $<0.05$ & $<0.001$ & ns \\
\hline SNAI3 & $1 \pm 0.57$ & $3.04 \pm 5.27$ & $2.18 \pm 2.20$ & 0.0171 & ns & $<0.05$ & ns \\
\hline SPRY4 & $1 \pm 0.46$ & $3.48 \pm 2.21$ & $2.40 \pm 1.85$ & $<0.0001$ & $<0.001$ & $<0.01$ & ns \\
\hline STAT3 & $1 \pm 0.47$ & $1.47 \pm 1.15$ & $1.97 \pm 1.70$ & 0.0112 & ns & $<0.01$ & ns \\
\hline TCF3 & $1 \pm 0.45$ & $1.66 \pm 1.32$ & $1.70 \pm 1.13$ & ns & ns & ns & ns \\
\hline TWIST1 & $1 \pm 0.47$ & $1.85 \pm 2.46$ & $1.12 \pm 0.78$ & ns & ns & ns & ns \\
\hline ZEB1 & $1 \pm 0.52$ & $0.69 \pm 0.52$ & $0.49 \pm 0.23$ & 0.0007 & $<0.05$ & $<0.001$ & ns \\
\hline ZEB2 & $1 \pm 0.51$ & $0.84 \pm 0.67$ & $0.68 \pm 0.55$ & 0.0429 & ns & $<0.05$ & ns \\
\hline
\end{tabular}

ECM, extracellular matrix; EMT, epithelial-to-mesenchymal transition; ns, not significant; NT, normal thyroid tissues; PTC, papillary thyroid carcinoma; wt, wild type. 
$\mathbf{A}$

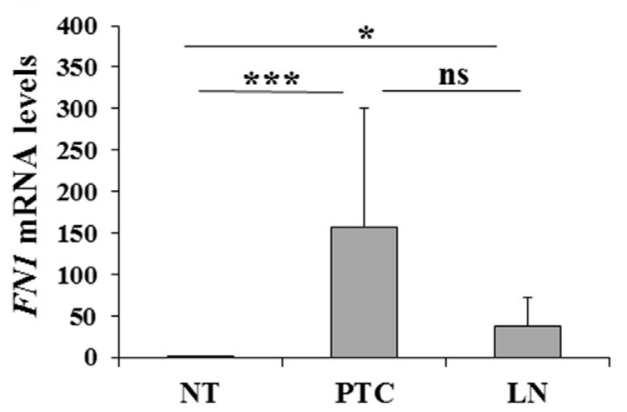

C

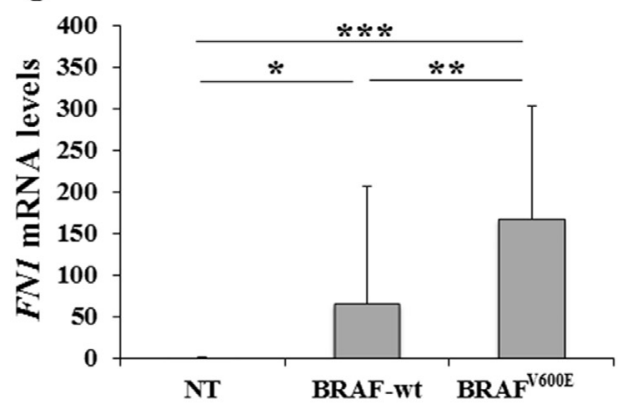

B

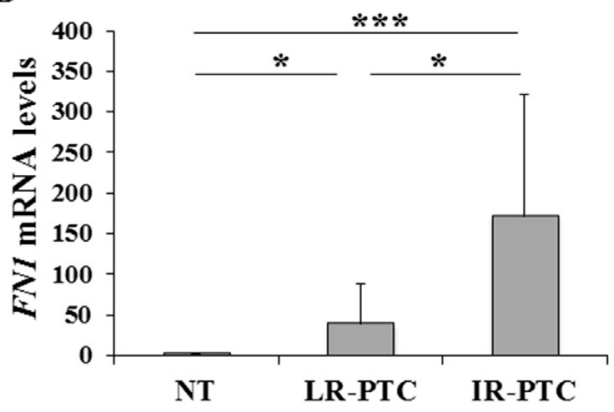

D

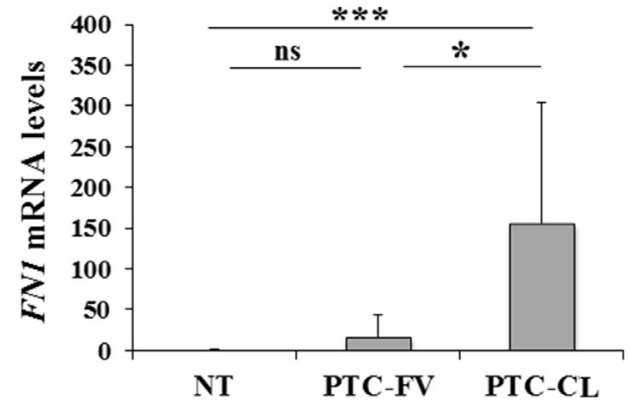

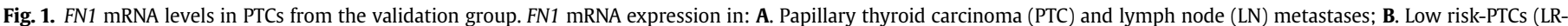

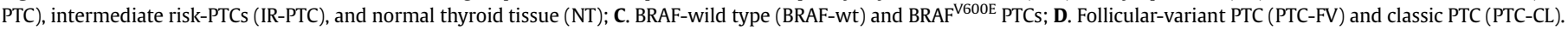

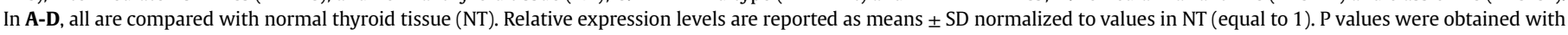
the Kruskal Wallis test followed by Dunn's multiple comparisons test. ${ }^{*} \mathrm{p}<0.05,{ }^{* *} \mathrm{p}<0.01,{ }^{* * *} \mathrm{p}<0.001$. ns, not significant.

\section{Discussion}

Novel targeted therapies are needed for the $20-30 \%$ of PTC patients who fail to respond to current approaches based on surgery plus radioiodine therapy. Efforts are thus being made to elucidate the molecular mechanisms underlying the enhanced aggressiveness of certain PTCs. The lack of responsiveness to radioiodine of recurrent/metastatic PTC lesions is largely the result of de-differentiation, in particular, the downregulated or abrogated

\section{IR-PTC}

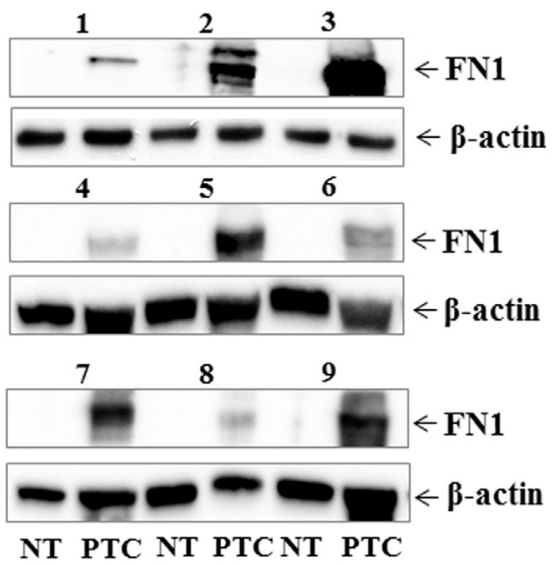

Fig. 2. Expression of FN1 in a subgroup of IR-PTCs from the validation group. Western blot analysis revealed a band of approximately $250 \mathrm{kDa}$, corresponding to human FN1 protein, in the total protein extracts from normal (NT) and tumor (PTC) tissues from 9 patients, numbered 1 to 9 . Data shown are relative to a representative group of IRPTCs. $\beta$-actin was used as loading control. expression of a functioning form of the sodium/iodide symporter (Arturi et al., 2000, 2001; Kogai and Brent, 2012; Schlumberger et al., 2007). Loss of differentiation, which is usually accompanied by dysregulated cell proliferation, is the result of genetic and epigenetic alterations that are characteristic of the more aggressive PTCs. The identification of some of alterations has led to the development of novel forms of molecularly targeted therapies for these tumors, which are currently under investigation (Fagin and Mitsiades, 2008; Russo et al., 2011, 2013; Xing, 2013; Galrão et al., 2013; Spitzweg et al., 2014; Carneiro et al., 2015). However, more complete characterization of individual tumors, including clinical, biological, and molecular features, can also provide valuable information.

In this study, we first examined the expression of several EMT markers in a group of 36 PTCs and their relation to ATA risk classes (Haugen et al., 2016) and BRAF ${ }^{V 600 E}$ mutational statuses. Consistent with the view of EMT as a sign of cancer progression (Vasko et al., 2007), our findings revealed higher levels of almost all the EMT genes in PTCs characterized by IR rather than LR. Moreover, our data provide additional information regarding a higher expression detected in the PTC-CL as opposed to PTC-FV histotypes, and in the $\mathrm{BRAF}^{\mathrm{V} 600 \mathrm{E}}$ PTCs compared to BRAF-wt PTCs. These findings were not surprising. Recent reports have highlighted enormous differences between the overall gene expression profiles of PTC-CL and PTC-FV (see the cancer Genome Research Atlas, 2014), and substantial changes in the ECM have been attributed to mutational activation of BRAF (Nucera et al., 2011; Riesco-Eizaguirre et al., 2009; Knauf et al., 2011; Baquero et al., 2013).

Among the EMT markers that we assessed, the most markedly upregulated gene was FN1. As confirmed in the validation series (50 PTCs, 6 LNs), the largest PTC-related increases in FN1 mRNA levels were associated with IR ( $v s$ LR), $\operatorname{BRAF}^{\mathrm{V} 600 \mathrm{E}}$ ( $v s$ BRAF-wt), and PTC-CL vs PTC-FV histotypes. These findings are fully consistent with the TCGA data set (Broad Institute TCGA Genome Data Analysis 

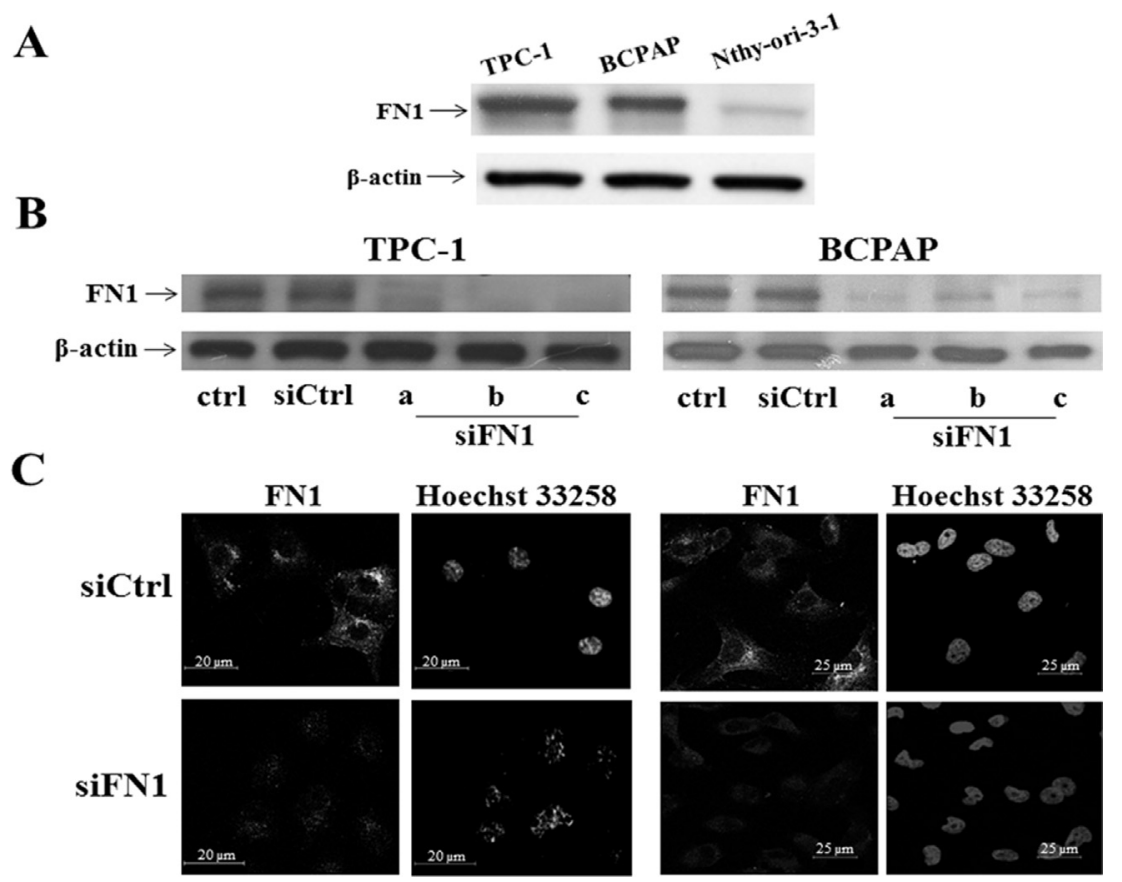

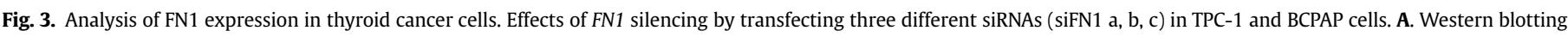

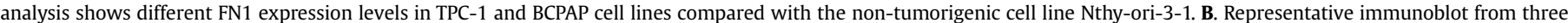

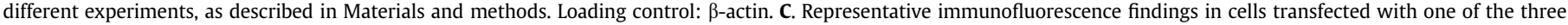

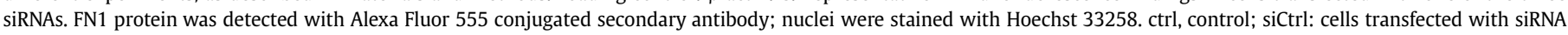
sequence control.

Center, 2015) and with a recent evidence of FN1 genomic amplifications found in a series of aggressive PTCs (Passon et al., 2015).

Gain of fibronectin is one of the defining features of EMT (Jung
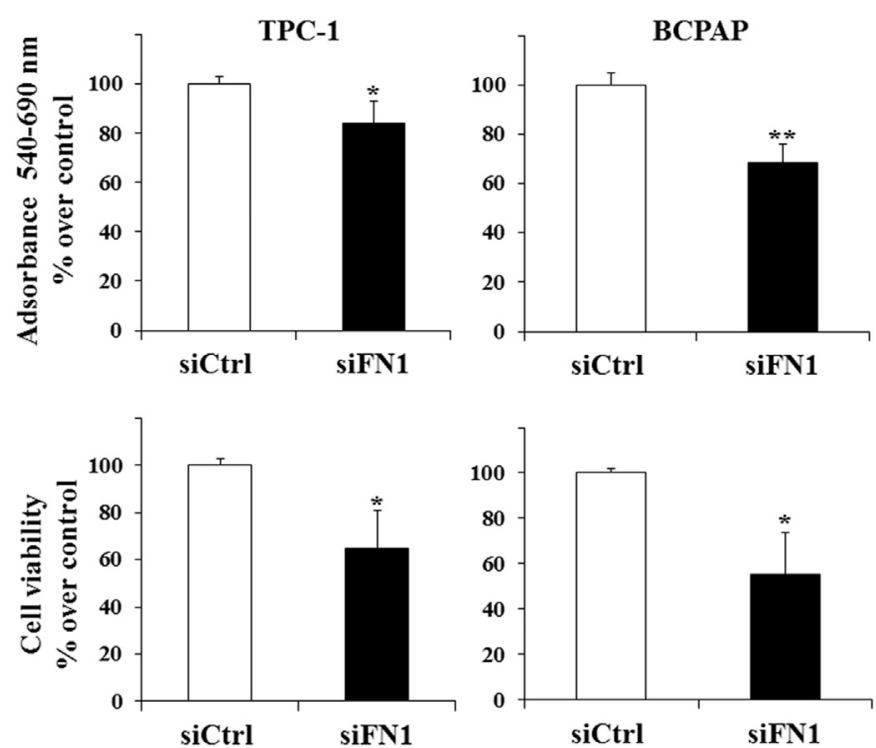

Fig. 4. FN1 silencing reduced proliferation of TPC-1 and BCPAP cells. After FN1 silencing, cells were plated and $24 \mathrm{~h}$ later viability was evaluated by MTT (upper panel) and count (lower panel) assays, as described in Materials and methods. Data relative to siFN1 are expressed as means of results obtained with the three different FN1 siRNAs. Results show average viability $(+\mathrm{SD})$ of TPC -1 and BCPAP (plated eight or three times for MTT and count assay, respectively) treated with siRNA sequence control (siCtrl, white bar) or FN1 siRNAs (siFN1, black bar). Results in figure were obtained from a single experiment and were confirmed in other two independent experiments. Statistical analysis was performed using the Tukey-Kramer multiple comparisons test. ${ }^{*} \mathrm{p}<0.05,{ }^{* *} \mathrm{p}<0.01$. et al., 2015): it alters the composition of the ECM and is believed to contribute to the invasive properties of cancers. Indeed, many studies have documented an association between FN1 expression and the invasive capacities of cells from various cancers, including those of the ovary, breast, and prostate (Yousif, 2014; Jeon et al., 2015; Pal et al., 2013). Moreover, several groups described overexpression of FN1 in thyroid cancer based on analysis of tumor tissue specimens or fine needle aspiration biopsies (FNAB) (Fryknäs et al., 2006; Prasad et al., 2005; Rodrigues et al., 2007; Griffith et al., 2006; Huang et al., 2001). FN1 expression has also been proposed as molecular marker for identifying malignant lesions among those with indeterminate FNABs (Fujarewicz et al., 2007; da Silveira Mitteldorf et al., 2011), and there is even some immunohistochemical evidence that increased FN1 expression is localized mainly in the invasive front of thyroid cancers (Vasko et al., 2007). These findings indicate that FN1-like other EMT-related proteins-is a negative prognostic marker in patients with PTC (Vasko et al., 2007; Montemayor-Garcia et al., 2013). Nonetheless, an in-depth investigation of its biopathological role in thyroid cancer has never been undertaken.

To address this issue, we used an in vitro gene silencing approach in two cell lines carrying the most common genetic alterations detected in human PTCs. FN1 silencing was associated with a significant reduction in the proliferation rate and, more importantly, decreases in cell adhesion, migration, and invasive capacities. These effects were observed in both cell lines, but, in accordance with our in vivo data on $B R A F^{V 600 E}$ tumors, the decreased proliferation and migration were particularly evident in BCPAP cells, which harbor the BRAF $F^{V 600 E}$ mutation, than in the TPC1 line. Although the more markedly diminished migration observed in BCPAP siFN1 cells might be partly the result of higher intra-assay cell mortality, the link between FN1 and $B R A F^{V 600 E}$ mutation is also supported by the reduced FN1 expression observed in BCPAP cells after treatment with the BRAF inhibitor PLX4032. 


\section{TPC-1}

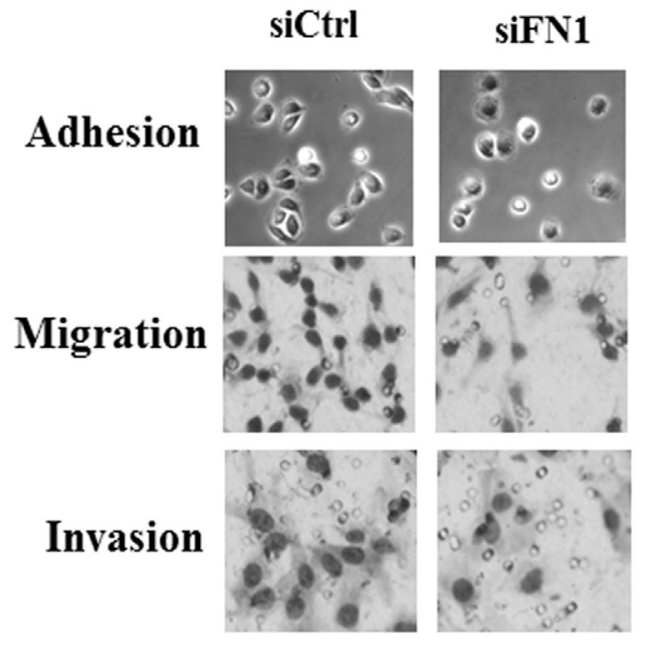

BCPAP

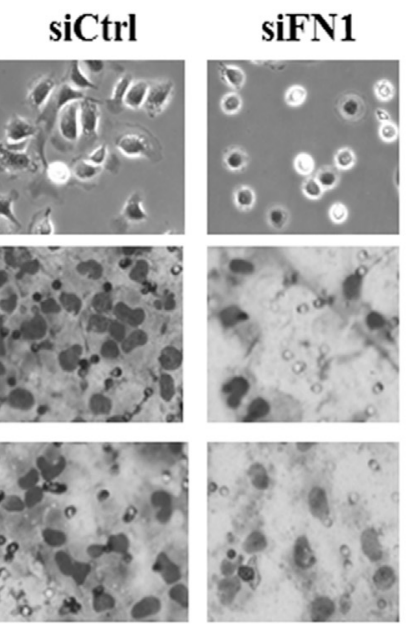

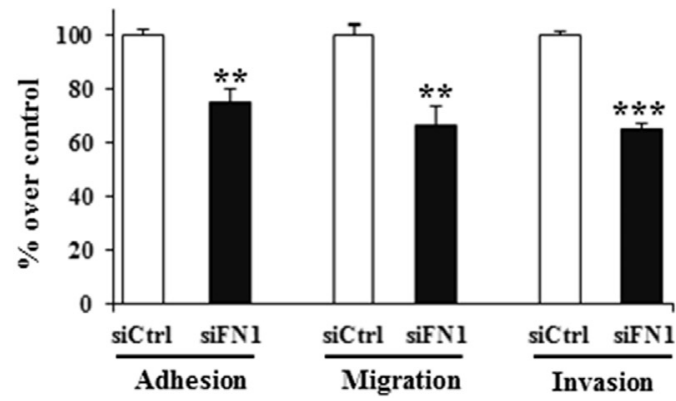

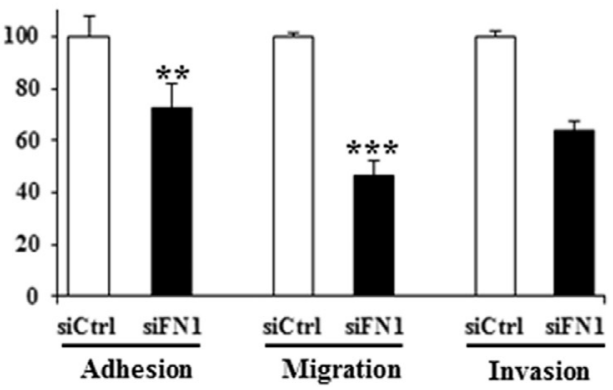

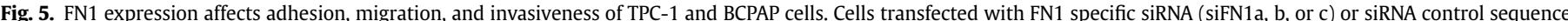

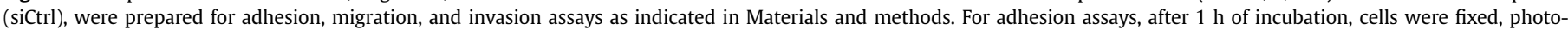

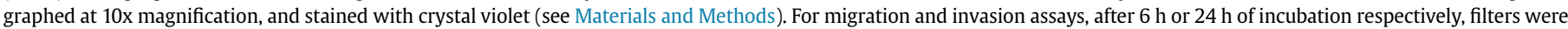

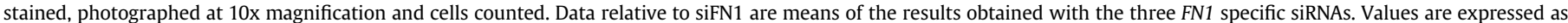

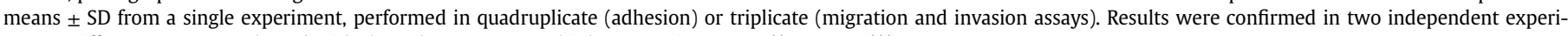
ments. Differences were evaluated with the Tukey-Kramer multiple comparisons test. ${ }^{* *} \mathrm{p}<0.01,{ }^{* * *} \mathrm{p}<0.001$.

It has been shown that cooperation between the nuclear proteins Snail1, p65NF-kB, and PARP1 occurs to activate the expression of FN1 in cells undergoing EMT (Stanisavljevic et al., 2011). These data shed light on the mechanism underlying FN1 overexpression in PTCs since these tumors are characterized by increased expression of Snail and p65NF-kB (Hardy et al., 2007; Zhang et al., 2014). In addition, we have shown that PARP1 inhibition diminishes

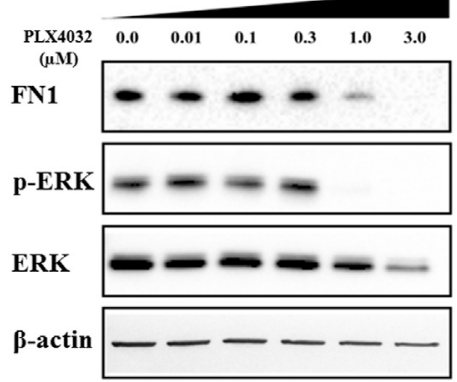

Fig. 6. BRAF inhibition induced a reduction of FN1 expression. BCPAP cells were treated with the indicated concentrations of PLX4032 for $24 \mathrm{~h}$ and FN1 expression was measured at each concentration as described in Material and methods. BRAF inhibition was evaluated by western blot analysis of p-ERK. $\beta$-actin and ERK were used as loading control. proliferation and induces differentiation in thyroid cancer cell lines (Lavarone et al., 2013). These results predict that treatment of PTC with PARP1 inhibitors might be capable of inhibiting the EMT, thereby offering benefits for patients with more aggressive forms of these tumors.

Finally, our findings demonstrate that FN1 overexpression characterizes the more aggressive PTCs and may play an important role during thyroid tumor progression by influencing the migration and invasion properties of neoplastic cells. Its relationship with $\mathrm{BRAF}^{\mathrm{V} 600 \mathrm{E}}$ and PTC-CL may suggest to further investigate FN1 as molecular target in this selected group of tumors.

\section{Acknowledgments}

This study was funded by grants from the Italian Ministry of Universities and Research (MIUR/Cofin 2010-2011 to D.R., 2010NFB9L_003) and from the Fondazione Umberto Di Mario ONLUS. The manuscript was edited by Marian Everett Kent, BSN.

\section{Appendix A. Supplementary data}

Supplementary data related to this article can be found at http:// dx.doi.org/10.1016/j.mce.2016.05.007. 


\section{References}

Arturi, F., Russo, D., Giuffrida, D., Schlumberger, M., Filetti, S., 2000. Sodium-iodide symporter (NIS) gene expression in lymph-node metastases of papillary thyroid carcinomas. Eur. J. Endocrinol. 143, 623-627.

Arturi, F., Russo, D., Bidart, J.M., Scarpelli, D., Schlumberger, M., Filetti, S., 2001. Expression pattern of the pendrin and sodium/iodide symporter genes in human thyroid carcinoma cell lines and human thyroid tumors. Eur. J. Endocrinol. $145,129-135$.

Baquero, P., Sánchez-Hernández, I., Jiménez-Mora, E., Orgaz, J.L., Jiménez, B., Chiloeches, A., 2013. (V600E)BRAF promotes invasiveness of thyroid cancer cells by decreasing E-cadherin expression through a snail-dependent mechanism. Cancer Lett. 335, 232-241.

Broad Institute TCGA Genome Data Analysis Center, 2015. Correlation between mRNAseq expression and clinical features. Broad Inst. MIT Harv. http:// dx.doi.org/10.7908/C18W3CM8.

Bulotta, S., Cerullo, A., Barsacchi, R., De Palma, C., Rotiroti, D., Clementi, E., Borgese, N., 2006. Endothelial nitric oxide synthase is segregated from caveolin1 and localizes to the leading edge of migrating cells. Exp. Cell. Res. 312, $877-889$.

Bulotta, S., Ierardi, M.V., Maiuolo, J., Cattaneo, M.G., Cerullo, A., Vicentini, L.M., Borgese, N., 2009. Basal nitric oxide release attenuates cell migration of HeLa and endothelial cells. Biochem. Biophys. Res. Commun. 386, 744-749.

Bulotta, S., Corradino, R., Celano, M., Maiuolo, J., D’Agostino, M., Oliverio, M., Procopio, A., Filetti, S., Russo, D., 2013. Antioxidant and antigrowth action of peracetylated oleuropein in thyroid cancer cells. J. Mol. Endocrinol. 51, 181-189.

Bulotta, S., Celano, M., Costante, G., Russo, D., 2016. Emerging strategies for managing differentiated thyroid cancers refractory to radioiodine. Endocrine 52 , $214-221$.

Carneiro, R.M., Carneiro, B.A., Agulnik, M., Kopp, P.A., Giles, F.J., 2015. Targeted therapies in advanced differentiated thyroid cancer. Cancer Treat. Rev. 41 (8), 690-698.

Celano, M., Maggisano, V., De Rose, R.F., Bulotta, S., Maiuolo, J., Navarra, M., Russo, D., 2015. Flavonoid fraction of Citrus reticulata juice reduces proliferation and migration of anaplastic thyroid carcinoma cells. Nutr. Cancer 67 (7), 1183-1190.

da Silveira Mitteldorf, C.A., de Sousa-Canavez, J.M., Leite, K.R., Massumoto, C., Camara-Lopes, L.H., 2011. FN1, GALE, MET, and QPCT overexpression in papillary thyroid carcinoma: molecular analysis using frozen tissue and routine fineneedle aspiration biopsy samples. Diagn. Cytopathol. 39 (8), 556-561.

D’Agostino, M., Voce, P., Celano, M., Sponziello, M., Moretti, S., Maggisano, V. Verrienti, A., Durante, C., Filetti, S., Puxeddu, E., Russo, D., 2012. Sunitinib exerts only limited effects on the proliferation and differentiation of anaplastic thyroid cancer cells. Thyroid 22, 138-144.

Durante, C., Puxeddu, E., Ferretti, E., Morisi, R., Moretti, S., Bruno, R., Barbi, F., Avenia, N., Scipioni, A., Verrienti, A., Tosi, E., Cavaliere, A., Gulino, A., Filetti, S. Russo, D., 2007. BRAF mutations in papillary thyroid carcinomas inhibit genes involved in iodine metabolism. J. Clin. Endocrinol. Metab. 92 (7), 2840-2843.

Fagin, J.A., Mitsiades, N., 2008. Molecular pathology of thyroid cancer: diagnostic and clinical implications. Best. Pract. Res. Clin. Endocrinol. Metab. 22, 955-969.

Fryknäs, M., Wickenberg-Bolin, U., Göransson, H., Gustafsson, M.G., Foukakis, T., Lee, J.J., Landegren, U., Höög, A., Larsson, C., Grimelius, L., Wallin, G. Pettersson, U., Isaksson, A., 2006. Molecular markers for discrimination of benign and malignant follicular thyroid tumors. Tumour Biol. 27 (4), 211-220.

Fujarewicz, K., Jarzab, M., Eszlinger, M., Krohn, K., Paschke, R., OczkoWojciechowska, M., Wiench, M., Kukulska, A., Jarzab, B., Swierniak, A., 2007. A multi-gene approach to differentiate papillary thyroid carcinoma from benign lesions: gene selection using support vector machines with bootstrapping. Endocr. Relat. Cancer 14 (3), 809-826.

Galrão, A.L., Sodré, A.K., Camargo, R.Y., Friguglietti, C.U., Kulcsar, M.A., Lima, E.U., Medeiros-Neto, G., Rubio, I.G., 2013. Methylation levels of sodium-iodide symporter (NIS) promoter in benign and malignant thyroid tumors with reduced NIS expression. Endocrine 43, 225-229.

Griffith, O.L., Melck, A., Jones, S.J., Wiseman, S.M., 2006. Meta-analysis and metareview of thyroid cancer gene expression profiling studies identifies important diagnostic biomarkers. J. Clin. Oncol. 24 (31), 5043-5051.

Hardy, R.G., Vicente-Duenas, C., Gonzalez-Herrero, I., Anderson, C., Flores, T. Hughes, S., Tselepis, C., Ross, J.A., 2007. Snail family transcription factors are implicated in thyroid carcinogenesis. Am. J. Pathol. 171, 1037-1046.

Haugen, B.R., Alexander, E.K., Bible, K.C., Doherty, G., Mandel, S.J., Nikiforov, Y.E. Pacini, F., Randolph, G., Sawka, A., Schlumberger, M., Schuff, K.G., Sherman, S.I., Sosa, J.A., Steward, D., Tuttle, R.M., Wartofsky, L., 2016. 2015 American thyroid association management guidelines for adult patients with thyroid nodules and differentiated thyroid cancer. Thyroid 26, 1-133.

Huang, Y., Prasad, M., Lemon, W.J., Hampel, H., Wright, F.A., Kornacker, K., LiVolsi, V. Frankel, W., Kloos, R.T., Eng, C., Pellegata, N.S., de la Chapelle, A., 2001. Gene expression in papillary thyroid carcinoma reveals highly consistent profiles. Proc. Natl. Acad. Sci. U. S. A. 98 (26), 15044-15049.

Huber, M.A., Kraut, N., Beug, H., 2005. Molecular requirements for epithelialmesenchymal transition during tumor progression. Curr. Opin. Cell Biol. 17 (5), 548-558.

Jeon, M., Lee, J., Nam, S.J., Shin, I., Lee, J.E., Kim, S., 2015. Induction of fibronectin by HER2 overexpression triggers adhesion and invasion of breast cancer cells. Exp. Cell. Res. 333 (1), 116-126.
Jung, H.Y., Fattet, L., Yang, J., 2015. Molecular pathways: linking tumor microenvironment to epithelial-mesenchymal transition in metastasis. Clin. Cancer Res. 21 (5), 962-968.

Knauf, J.A., Sartor, M.A., Medvedovic, M., Lundsmith, E., Ryder, M., Salzano, M., Nikiforov, Y.E., Giordano, T.J., Ghossein, R.A., Fagin, J.A., 2011. Progression of BRAF-induced thyroid cancer is associated with epithelial-mesenchymal transition requiring concomitant MAP kinase and TGF $\beta$ signaling. Oncogene 30 (28), 3153-3162.

Kogai, T., Brent, G.A., 2012. The sodium iodide symporter (NIS): regulation and approaches to targeting for cancer therapeutics. Pharmacol. Ther. 135, 355-370.

Lavarone, E., Puppin, C., Passon, N., Filetti, S., Russo, D., Damante, G., 2013. The PARP inhibitor PJ34 modifies proliferation, NIS expression and epigenetic marks in thyroid cancer cell lines. Mol. Cell. Endocrinol. 365 (1), 1-10.

Liu, W., Asa, S.L., Ezzat, S., 2005. 1alpha,25-Dihydroxyvitamin D3 targets PTENdependent fibronectin expression to restore thyroid cancer cell adhesiveness. Mol. Endocrinol. 19 (9), 2349-2357.

Maggisano, V., Puppin, C., Celano, M., D’Agostino, M., Sponziello, M., Micali, S., Navarra, M., Damante, G., Filetti, S., Russo, D., 2014. Cooperation of histone deacetylase inhibitors SAHA and valproic acid in promoting sodium/iodide symporter expression and function in rat Leydig testicular carcinoma cells. Endocrine 45 (1), 148-152.

Mehra, S., Tuttle, R.M., Milas, M., Orloff, L., Bergma, D., Bernet, V., Brett, E., Cobin, R., Doherty, G., Judson, B.L., Klopper, J., Lee, S., Lupo, M., Machac, J., Mechanick, J.I., Randolph, G., Ross, D.S., Smallridge, R., Terris, D., Tufano, R., Alon, E., Clain, J., Dos Reis, L., Scherl, S., Urken, M.L., 2015. Database and registry research in thyroid cancer: striving for a new and improved national thyroid cancer database. Thyroid 25 (2), 157-168.

Montemayor-Garcia, C., Hardin, H., Guo, Z., Larrain, C., Buehler, D., Asioli, S., Chen, H., Lloyd, R.V., 2013. The role of epithelial mesenchymal transition markers in thyroid carcinoma progression. Endocr. Pathol. 24 (4), 206-212.

Nucera, C., Goldfarb, M., Hodin, R., Parangi, S., 2009. Role of B-RafV600E in differentiated thyroid cancer and preclinical validation of compounds against BRafV600E. Biochim. Biophys. Acta 1795 (2), 152-161.

Nucera, C., Lawler, J., Parangi, S., 2011. BRAF(V600E) and microenvironment in thyroid cancer: a functional link to drive cancer progression. Cancer Res. 71 (7), 2417-2422.

Pal, S., Ganguly, K.K., Chatterjee, A., 2013. Extracellular matrix protein fibronectin induces matrix metalloproteinases in human prostate adenocarcinoma cells PC3. Cell Commun. Adhes. 20 (5), 105-114.

Passon, N., Bregant, E., Sponziello, M., Dima, M., Rosignolo, F., Durante, C., Celano, M., Russo, D., Filetti, S., Damante, G., 2015. Somatic amplifications and deletions in genome of papillary thyroid carcinomas. Endocrine 50, 453-464.

Prasad, M.L., Pellegata, N.S., Huang, Y., Nagaraja, H.N., de la Chapelle, A., Kloos, R.T., 2005. Galectin-3, fibronectin-1, CITED-1, HBME1 and cytokeratin-19 immunohistochemistry is useful for the differential diagnosis of thyroid tumors. Mod. Pathol. 18, 48-57.

Puppin, C., Fabbro, D., Dima, M., Di Loreto, C., Puxeddu, E., Filetti, S., Russo, D., Damante, G., 2008. High periostin expression correlates with aggressiveness in papillary thyroid carcinomas. J. Endocrinol. 197 (2), 401-408.

Puxeddu, E., Durante, C., Avenia, N., Filetti, S., Russo, D., 2008. Clinical implications of BRAF mutation in thyroid carcinoma. Trends Endocrinol. Metab. 19 (4), $138-145$.

Riesco-Eizaguirre, G., Rodríguez, I., De la Vieja, A., Costamagna, E., Carrasco, N., Nistal, M., Santisteban, P., 2009. The BRAFV600E oncogene induces transforming growth factor beta secretion leading to sodium iodide symporter repression and increased malignancy in thyroid cancer. Cancer Res. 69 (21), 8317-8325.

Rodrigues, R., Roque, L., Espadinha, C., Pinto, A., Domingues, R., Dinis, J., Catarino, A., Pereira, T., Leite, V., 2007. Comparative genomic hybridization, BRAF, RAS, RET, and oligo-array analysis in aneuploid papillary thyroid carcinomas. Oncol. Rep. 18 (4), 917-926.

Rosignolo, F., Maggisano, V., Sponziello, M., Celano, M., Di Gioia, C.R., D’Agostino, M., Giacomelli, L., Verrienti, A., Dima, M., Pecce, V., Durante, C., 2015. Reduced expression of THR $\beta$ in papillary thyroid carcinomas: relationship with BRAF mutation, aggressiveness and miR expression. J. Endocrinol. Invest. 38, 1283-1289.

Russo, D., Damante, G., Puxeddu, E., Durante, C., Filetti, S., 2011. Epigenetics of thyroid cancer and novel therapeutic targets. J. Mol. Endocrinol. 46, R73-R81.

Russo, D., Durante, C., Bulotta, S., Puppin, C., Puxeddu, E., Filetti, S., Damante, G., 2013. Targeting histone deacetylase in thyroid cancer. Expert Opin. Ther. Targets 17, 179-193.

Schlumberger, M., Lacroix, L., Russo, D., Filetti, S., Bidart, J.M., 2007. Defects in iodide metabolism in thyroid cancer and implications for the follow-up and treatment of patients. Nat. Clin. Pract. Endocrinol. Metab. 3, 260-269.

Schweppe, R.E., Klopper, J.P., Korch, C., Puqazhenthi, U., Benezra, M., Knauf, J.A., Fagin, J.A., Marlow, L.A., Copland, J.A., Smallridge, R.C., Haugen, B.R., 2008. Deoxyribonucleic acid profiling analysis of 40 human thyroid cancer cell lines reveals cross-contamination resulting in cell line redundancy and misidentification. J. Clin. Endocrinol. Metab. 93 (11), 4331-4341.

Spitzweg, C., Bible, K.C., Hofbauer, L.C., Morris, J.C., 2014. Advanced radioiodinerefractory differentiated thyroid cancer: the sodium iodide symporter and other emerging therapeutic targets. Lancet Diabetes Endocrinol. 2, 830-842.

Sponziello, M., Lavarone, E., Pegolo, E., Di Loreto, C., Puppin, C., Russo, M.A., Bruno, R., Filetti, S., Durante, C., Russo, D., Di Cristofano, A., Damante, G., 2013. Molecular differences between human thyroid follicular adenoma and 
carcinoma revealed by analysis of a murine model of thyroid cancer. Endocrinology 154, 3043-3053.

Sponziello, M., Verrienti, A., Rosignolo, F., De Rose, R.F., Pecce, V., Maggisano, V. Durante, C., Bulotta, S., Damante, G., Giacomelli, L., Di Gioia, C.R., Filetti, S., Russo, D., Celano, M., 2015. PDE5 expression in human thyroid tumors and effects of PDE5 inhibitors on growth and migration of cancer cells. Endocrine 50 (2), 434-441.

Stanisavljevic, J., Porta-de-la-Riva, M., Batlle, R., de Herreros, A.G., Baulida, J., 2011. The p65 subunit of NF- $\mathrm{KB}$ and PARP1 assist Snail1 in activating fibronectin transcription. J. Cell Sci. 124 (Pt 24), 4161-4171.

Thiery, J.P., Sleeman, J.P., 2006. Complex networks orchestrate epithelialmesenchymal transitions. Nat. Rev. Mol. Cell Biol. 7 (2), 131-142.

Udelsman, R., Zhang, Y., 2014. The epidemic of thyroid cancer in the United States: the role of endocrinologists and ultrasounds. Thyroid 24 (3), 472-479.

Vasko, V., Espinosa, A.V., Scouten, W., He, H., Auer, H., Liyanarachchi, S., Larin, A., Savchenko, V., Francis, G.L., de la Chapelle, A., Saji, M., Ringel, M.D., 2007. Gene expression and functional evidence of epithelial-to-mesenchymal transition in papillary thyroid carcinoma invasion. Proc. Natl. Acad. Sci. U. S. A. 104 (8), 2803-2808.

Xing, J., Liu, R., Xing, M., Trink, B., 2011. The BRAFT1799A mutation confers sensitivity of thyroid cancer cells to the BRAFV600E inhibitor PLX4032 (RG7204). Biochem. Biophys. Res. Commun. 404, 958-962.

Xing, M., 2013. Molecular pathogenesis and mechanisms of thyroid cancer. Nat. Rev. Cancer 13, 184-199.

Yousif, N.G., 2014. Fibronectin promotes migration and invasion of ovarian cance cells through up-regulation of FAK-PI3K/Akt pathway. Cell Biol. Int. 38 (1) 85-91.

Zhang, Y., Meng, Z., Zhang, M., Tan, J., Tian, W., He, X., Fu, Q., Xu, K., He, Q., Zhu, M. Li, X., Zhang, G., He, Y., Jia, Q., Zhang, J., Wang, S., Song, X., 2014. Immunohistochemical evaluation of midkine and nuclear factor-kappa B as diagnostic biomarkers for papillary thyroid cancer and synchronous metastasis. Life Sci. 118 (1), 39-45. 